\section{Selfish psycho-darwinism}

SIR - For my present purpose, I wish to imagine that Richard Dawkins and I are the sole sources of male chromosomes on a planet which has a large female population and which we both know will be the subject of unpredictable environmental changes over the coming millennia.

We have been given five wishes in respect of the 'evolvability' of the genetic inheritance we are to pass on. My rival, an honourable man, and confident that the selfish gene model cannot be improved upon, declines this offer. I, on the other hand, more machiavellian, and experienced in human selection methods, make the following stipulations:

(1) Each of my heirs must continually assess its performance in relation to a reference group made up of similar individuals, in all matters affecting genetic replication.

(2) Where its own assessments and the reactions of its peers reflect a comparatively high level of performance, it will experience a sense of well-being. This in turn will trigger physical responses that will act as a multiplier upon its rate of genetic replication by, for example, stimulating its libido and making it more active generally, further increasing its attractiveness to mates, discouraging predators, warding off diseases and intimidating rivals.

(3) Where its own assessments and the reactions of its peers reflect a comparatively poor performance, it will become depressed. The only means of relieving this depression will be: (i) to raise comparative performance; (ii) to adopt a well-received social role, supportive of the high achiever; (iii) to benefit from an environmental change to which it proves better suited than its peers (the 'Admirable Crichton Effect'); (iv) to break away from the reference group by successfully adopting a novel lifestyle.

(4) Where none of the above options is practical, its emotional state will trigger physical changes that will serve to eliminate it from the genetic stock by, for example, suppressing its libido, deterring mates, attracting predators, reducing resistance to disease and making rivals contemptuous.

(5) Where, as a result of option 3 (ii), increasingly complex social structures start to develop, genetic factors will start to produce different personality types in order to provide suitable candidates for each role.

A number of questions arise:

(a) Although the above is a simplification of an idea I have been developing for a decade, is it not clear that my 'evoholics' would outcompete Dawkins' heirs, leading to the latter's rapid extinction?

(b) Would they not similarly deal with any of their own kind who, through genetic variability, attempted to backslide to Dawkins' more laissez-faire regime?

(c) Have not various research findings over recent years shown that all the 'gifts' I have hypothetically given to my heirs actually exist, at least among some species? (See, for example, the 'Duke of Marlborough Effect', described on page 286 of the 1989 edition of The Selfish Gene. Other references can be supplied on request.)

(d) Does not this hypothesis elegantly synthesize the group selection and selfish gene models? After all, it is an individual whose genetic interests are optimized: $\mathrm{Mr}$ (or Mrs) Primogenitor. However, its outworkings would in some circumstances appear to show group selection at work, while in others seem to be totally focused upon the individuals currently bearing Primogenitor's genes.

(e) Finally, does it not answer, more fully than he was at that time able to, the following

\section{Cholera mystery}

SIR - I was surprised to see that you had reported that "Dr John Wood . . . removed the pump-handle from a polluted communal water supply in the City of London's Broad Street, bringing a cholera outbreak quickly to an end" (Nature 350, 640; 1991). Until now, I had always thought it was Dr John Snow who had removed the handle from the Broad Street pump. On examining several reliable references ${ }^{1-9}$, however, I have failed to find an actual statement that Dr Snow removed the handle. Thus, as sometimes happens in research, an assumption accepted as truth may be erroneous. Who actually did remove the handle?

\section{Philip Morris USA,}

Rebecca C. GantT

\section{Park Avenue,}

New York, New York 10017, USA

1. Mausner, J. S., \& Bahn, A. K. Epidemiology. An Introductory Text 93,94 (Saunders, Philadelphia, 1974)

2. Fox, J. P., Hall, C. E.\& Elveback, L. R. Epidemiology. Man and Disease. 2, 24-26. 28, 116, 167, 240. 284 (Macmilian. London, 1970).

3. Macmahon, B., \& Pugh, T.F. Epidemiotogy. Principles and Methods 7-10 (Little Brown, Boston, 1970).

4. Lilienfeld, A. M. Foundations of Epidemiology 24, 25 (Oxford University Press, New York, 1976).

5. Last, J. M. (ed.) A Dictionary of Epidemiology 2 nd Edn, 122 (Oxford University Press, New York, 1988).

6. Holland, W. W., Detels, R., Knox, G. \& Breeze, E. (eds) Oxford Textbook of Public Health, Vols 1 . IV (Oxford University Press, 1986).

7. Sartwell, P. E. (ed.) Maxcy-Rosenau Preventive Medicine and Public Health 10th Edn, 203 (Appleton-Century-Crofts. New York 1973)

8. Pelling. M. Cholera, Fover and English Medicine 1825-1865 Oxford Historical Monographs, 223-225 (Oxford University Press, 1978).

9. Benton, H. H. in The New Encyclopedia Britannica Vol. IX 302, 582 (Chicago. 1974).

SIR - The London physician involved in the cholera outbreak in the 1850 s was Dr John Snow not Dr John Wood. More information about his life history and work can be obtained from any reputable epidemiology text. The second error in your report is that he did not bring the cholera outbreak to an end by removing the pump handle as is generally thought. In fact, the epidemic was in its declining phase at that point. His action does, however, stress the need for epidemio- question raised by J. S. Price in the 29 July 1967 edition of The Lancet:

States of excessive depression, anxiety, and irritability are very common. Possibly one in seven of the population consult their general practitioners every year for some emotional disturbance. Why should this be so? We are the result of a process of natural selection, the length and ruthlessness of which confound the imagination. It is known that the severer mental disorders are associated with a reduced fertility, and it is more than likely that under primitive conditions even the milder states of depression conferred a disadvantage in the struggle for survival. Why then are we as a species lumbered with these most disagreeable tendencies - why are we all not paragons of calm, energetic happiness?

56 Tennyson Road,

Harpenden, Herts AL5 4BB, UK

M. J. C. WALLER

logists to take action rapidly; it has also led to one of the definitions of an epidemiologist, namely "someone who sails to glory on the declining phase of an epidemic".

Centre for Epidemiological

Research in Southern Africa,

PO Box 19070, Tygerberg 7505 ,

South Africa

\section{Help wanted}

SIR - During his 18 years of working life, Alan Dower Blumlein (1903-42) was awarded 128 patents for inventions which improved almost every aspect of telephony, sound recording, television and radar, and included in 1931 his Specification 394,325 for stereophony.

I am working on a biography of Blumlein and would be grateful if any of your readers could send me copies of documents they may have bearing on his work, including copies of published papers. Please mark the envelope 'BB' to arrive before mid-August 1991 if possible.

F. P. THOMSON

39 Church Road,

Watford, Herts WD1 3PY, UK

\section{All over now}

SIR - In his review of the book Too Hot to Handle: The Race for Cold Fusion by Frank Close (Nature 350, 29; 1991), Sir Brian Pippard concludes that the initial euphoria having now faded, the episode is "hardly more than a footnote to history", and that the institution of science is still robust. I should like to add a modern clerihew as a codicil to his comments:

The cheers for Cold Fusion

Were last year's illusion:

What's left of a quorum

Is the Pons Asinorum.

Harmon Craig

Scripps Institution of Oceanography,

University of California, San Diego,

La Jolla, California 92093, USA 